\title{
KORELASI PROKRASTINASI, GAME ONLINE, DAN MEDIA SOSIAL DENGAN MINAT BEROLAHRAGA PESERTA DIDIK PUTRA KELAS X SMKN 3 KINTAMANI
}

\author{
I Komang Putra Mahendra ${ }^{1}, \mathrm{H}$. Wahjoedi², I Ketut Semarayasa ${ }^{3}$ \\ 1,2,3 Program Studi S2 Pendidikan Olahraga, Pascasarjana Universitas Pendidikan Ganesha \\ Singaraja, Indonesia
}

e-mail: mahendrakomangputra@gmail.com, wahjoedi@undiksha.ac.id,

ketut.semarayasa@undiksha.ac.id

\begin{abstract}
Abstrak
Penelitian ini bertujuan untuk mengetahui korelasi prokrastinasi, game online, media sosial, dengan minat berolahraga. Populasi dalam penelitian ini adalah seluruh peserta didik putra kelas $X$ SMK Negeri 3 Kintamani, tahun pelajaran 2020/2021, berjumlah 146 siswa. Menggunakan teknik random sampling, didapatkan 75 siswa sebagai sampel. Jenis penelitian yang digunakan korelasi. Pengumpulan data menggunakan kuesioner. Analisis data menggunakan korelasi produk moment dan analisis regresi linier berganda. Hasil penelitian menunjukkan ; (1) $64,25 \%$ peserta didik melakukan kecenderungan prokrastinasi, game online, media sosial dan minat berolahraga. (2) terdapat korelasi positif prokrastinasi dengan minat berolahraga (nilai rhitung 0,496 > rtabel 0,227 dan Sig. $0,000<0,05$ ). (3) terdapat korelasi negatif game online dengan minat berolahraga (nilai rhitung $-0,241>$ rtabel 0,227 dan sig. $0,037<0,05$ ). (4) tidak terdapat korelasi media sosial dengan minat berolahraga, (nilai rhitung $-0,197<$ rtabel 0,227 dan nilai sig. 0,091 >0,05). (5) Sedangkan hasil analisis regresi linier menggunakan uji $F(12,249$ dan nilai sig. $0,000<0.05)$, artinya terdapat korelasi positif secara bersama-sama antara prokrastinasi, game online dan media sosial dengan minat berolahraga. Dari hasil penelitian tersebut dapat disimpulkan, bahwa (1) Terdapat korelasi positif antara Prokrastinasi dengan minat berolahraga peserta didik putra kelas X SMK Negeri 3 Kintamani, tahun pelajaran 2020/2021. (2) Terdapat korelasi negatif antara game online dengan minat berolahraga peserta didik putra kelas X SMK Negeri 3 Kintamani, tahun pelajaran 2020/2021. (3) tidak terdapat korelasi media sosial dengan minat berolahraga peserta didik putra kelas $X$ SMK Negeri 3 Kintamani tahun pelajaran 2020 / 2021 dan (4) terdapat korelasi positif prokrastinasi, game online, dan media sosial secara bersama-sama dengan minat berolahraga peserta didik putra kelas X SMK Negeri 3 Kintamani tahun pelajaran 2020/2021. Disarankan kepada guru atau pendidik, agar mengetahui pentingnya menangani masalah prokrastinasi, game online, media sosial dan minat berolahraga peserta didik, demi terciptanya proses belajar dan tercapainya tujuan pendidikan nasional. Diharapkan sekolah mampu mengambil suatu kebijakan dalam mengatasi permasalahan dalam peningkatan minat berolahraga peserta didik.
\end{abstract}

Kata-kata kunci: prokrastinasi, game online, media sosial, minat berolahraga.

\begin{abstract}
This study aims to describe and to determine the correlation of several variables, namely: (1) procrastination, (2) online games, (3) social media, and (4) interest in sports of class $X$ male learners of SMK Negeri 3 Kintamani in the academic year 2020 / 2021. The population in this study were all male students of class X SMK Negeri 3 Kintamani, academic year 2020/2021, in total 146 people. Determination of the sample in this study uses a random sampling technique, by taking samples of male learners in total of 75 people. This research is designed in the form of correlation research. The data in this study were collected using a questionnaire that related to procrastination, online games, social media and the interest in sports. Data were analyzed using product moment correlation and multiple linear regression analysis. The results show that (1) the average tendency of learners to procrastinate, online gaming, be in social media and show the interest in sports was (64.25\%). In the correlation results, there is a positive relationship between procrastination and interest in sports, where the calculated $r$ value is $0.496>r$ table is 0.227 and the Sig. (2-tailed) $X 1$ and $Y$ of $0.000<0.05$. The results of the correlation between online games and the interest in sport have a negative relationship in which
\end{abstract}


the $r$ count is $-0.241>r$ table 0.227 and the sig. (2-tailed) $X 2$ and $Y$ values are $0.037<0.05$. The results of the correlation between social media and the interest in sport have no relationship in which the calculated $r$ value is $-0.197<r$ table 0.227 and the sig. (2-tailed) $X 3$ and $Y$ values are $0.091>0.05$. While the results of linear regression analysis using the $F$ test obtained an $F$ value of 12.249 and a sig value. $0.000<0.05$. It means that there is a positive correlation at the same time, between procrastination, online games and social media with the students' interest in sports. From the results of the study it can be concluded that there is a correlation between procrastination, online games, and social media with the interest in exercising for male students of class X SMK Negeri 3 Kintamani in the 2020/2021 academic year. It is recommended that teachers or educators add insight into the importance of dealing with procrastination problems, online games, social media and students' interest in exercising, in order to create a learning process and achieve the National education goals. It is hoped that the school considers a policy in overcoming academic problems in increasing students' interest in sport activities.

Keywords: procrastination, online games, social media, interest in sport.

\section{PENDAHULUAN}

Pembinaan dan pengembangan IImu Olahraga telah menjadi prioritas dalam ranah keilmuan, hal ini disebabkan oleh salah satu indikator dan faktor manusia yang berkualitas, manusia yang berkualitas adalah manusia yang memiliki tingkat kesehatan dan kebugaran jasmani yang tinggi, baik secara fisik maupun psikologis. Untuk memenuhi kualitas sumber daya manusia, olahraga diarahkan pada peningkatan kualitas jasmani, mental dan rohani ditunjukkan untuk membentuk watak dan kepribadian, disiplin, sportifitas yang tinggi, dan peningkatan prestasi, serta meningkatkan moral bangsa. Hal ini juga sesuai Undang -Undang Nomor 3 tahun 2005 tentang Sistem Keolahragaan Nasional (INDONESIA, 2007). Tujuan pemerintah dalam bidang olahraga terdapat dalam BAB 2 Pasal 4 yang berbunyi: "Keolahragaan nasional bertujuan memelihara dan meningkatkan kesehatan dan kebugaran, prestasi, kualitas manusia, menanamkan nilai moral dan akhlak mulia, sportifitas, disiplin, mempererat dan membina persatuan dan kesatuan bangsa, memperkokoh ketahanan nasional, serta meningkatkan harkat, martabat dan kehormatan bangsa."

Tercapainya tujuan keolahragaan nasional akan terlihat dari tumbuh dan berkembangnya generasi yang sehat jasmani dan rohani, bugar, berkualitas, bermoral dan berakhlak mulia, sportif, disiplin yang nantinya akan berdampak terhadap pembangunan nasional bangsa ( national character building) (Husdarta, 2009). Sehingga olahraga merupakan bagian yang tidak terpisahkan dalam kehidupan sehari - hari, olahraga menjadi sarana strategis untuk membangun kepercayaan diri, identitas bangsa, dan menjadi kebanggaan nasional.mMenurut Undang - Undang No.20 tahun 2003 tentang Sistem Pendidikan Nasional bahwa Pendidikan Jasmani Olahraga dan Kesehatan (PJOK) merupakan bagian integral dari pendidikan secara keseluruhan, bertujuan untuk mengembangkan aspek kebugaran jasmani, keterampilan gerak, keterampilan berpikir kritis, keterampikan sosial, penalaran, stabilitas emosional, tindakan moral, aspek pola hidup sehat dan pengenalan lingkungan bersih melalui aktivitas jasmani, olahraga dan kesehatan terpilih yang direncanakan secara sistematis dalam rangka mencapai tujuan Pendidikan Nasional.

Sesuai yang diamanatkan dalam Undang - Undang Sistem Keolahragaan Nasional tahun 2005 pasal 17 tentang ruang lingkup keolahragaan yang dikenal dengan tiga pilar Sistem Keolahragaan Nasional meliputi ; (1) Olahraga Pendidikan. Olahraga pendidikan adalah olahraga dengan tujuan untuk pendidikan maka semua aktivitas gerak diarahkan untuk memenuhi tujuan pendidikan. Oleh karena itu, olahraga yang bertujuan untuk pendidikan identik dengan aktivitas pendidikan jasmani yang ditemukan di sekolah sekolah dengan implikasinya. (2) Olahraga Rekreasi. Olahraga Rekreasi adalah jenis kegiatan olahraga yang dilakukan pada waktu senggang atau waktu luang, berdasarkan keinginan atau kehendak yang timbul karena memberi kepuasan atau kesenangan. dan (3) Olahraga Prestasi. Olahraga prestasi adalah cabang olahraga dengan tujuan untuk 
meraih suatu prestasi. Olahraga prestasi dilakukan oleh setiap orang yang memiliki minat, bakat, motivasi, kemampuan dan prestasi. Pengembangan dan peningkatan prestasi olahraga perlu dilakukan pembinaan sejak dini melalui pembentukan minat, bakat, motivasi, pendidikan dan pelatihan olahraga.

Dari hasil penelitian (Diananda, 2019) bahwa usia anak menaruh minat terhadap aktivitas olahraga, dimulai pada umur 8-11 tahun memiliki minat olahraga yang besar, mulai pada umur 12-14 tahun minat berolahraga anak tersebut menurun." Lalu untuk mengembangkan dan menjaga pembentukan minat ,bakat dan motivasi aktivitas berolahraga , peran orang tua sebagai pendukung dalam pengadaan fasilitas, menciptakan suasana kondusif,dan penguatan positif. Selain itu lebih menitik beratkan pada motivasi intrinsik, untuk memupuk minat dan kesenangan untuk berolahraga. Peranan orang lain hanyalah sebagai pemacu dalam mendorong minat untuk mencapai prestasi, karena olahraga prestasi merupakan muara dari seluruh hasil berbagai pembinaan yang dilakukan secara terus menerus dengan acuan program pelatihan yang terpadu, terarah dan berkesinambungan berdasarkan ilmu pengetahuan dan teknologi keolahragaan yang modern.

Pada jaman modern ini, olahraga tidak lagi sebagai aktivitas rutin yang dilakukan kebanyakan orang untuk mendapatkan kesehatan dan kebugaran, mengingat ada kecenderungan dalam kehidupan manusia dewasa ini, minat untuk beraktivitas fisik atau berolahraga makin berkurang, karena perkembangan dan kemajuan teknologi, hampir segala aktivitas dilakukan dengan teknologi sehingga fungsi gerak tubuh semakin berkurang(Candra, 2020). Untuk dapat menumbuhkan kegemaran berolahraga peserta didik menjadi bagian penting dan tantangan tersendiri bagi para guru pendidikan jasmani di sekolah.

Menyikapi perkembangan teknologi khususnya perkembangan gawai dan atau smartphone yang semakin canggih sehingga cenderung anak usia remaja dewasa bahkan orang tua seakan terbuai dan terlena dengan sebuah aplikasi seperti permainan game online dan social media. Implikasinya bagi mereka yang kecanduan game online dan social media tentunya akan semakin sering melupakan aktivitas fisik salah satunya berolahraga. Menurut (Sekretaris Kemenpora (Prasetyo, 2013) bahwa partisipasi penduduk yang berumur 10 tahun ke atas terjadi penurunan aktivitas olahraga dari waktu ke waktu. Peningkatan partisipasi olahraga hanya terjadi dari tahun 2000 sebesar $22,6 \%$ menuju tahun 2003 menjadi sebesar $25,4 \%$. Dalam kurun waktu tahun 2003, ke tahun 2006, menurun $23,2 \%$ dan pada tahun 2009 partisipasi penduduk dalam melakukan olahraga terus menurun, menjadi $21,8 \%$. Pola tersebut berlaku baik di daerah perkotaan maupun pedesaan. Hal tersebut tidak lepas dari kehadiran teknologi pada abad 21 yang dimulai pada tahun 2001, di era milenial yang semakin canggih ini, terjadi perubahan teknologi dan pertukaran informasi yang sangat cepat. Diperkirakan lebih dari 100 juta dari 250 juta orang warga Indonesia menjadi pengguna aktif ponsel pintar pada tahun 2018, sehingga Indonesia termasuk berada pada peringkat ke empat dunia setelah Cina, India dan Amerika, (KOMINFO dalam Lutfiwati,2018). Melalui ponsel pintar ini, masyarakat Indonesia semakin dimudahkan terhubung dengan jaringan internet hingga ke pelosok - pelosok desa jaringan internet saat ini telah disediakan. Dengan demikian masyarakat sudah mulai mengubah gaya hidup mereka, sehingga mempengaruhi setiap aktivitas sisi kehidupan setiap orang saat ini. Perkembangan teknologi yang canggih dan sangat mudah diakses oleh siapa saja, telah dikemas dalam berbagai media diantaranya smartphone maupun komputer, dalam kemanfaatannya ada dua dampak yang ditimbulkan, dari sisi dampak positifnya, teknologi memudahkan seseorang untuk mengakses informasi, dalam hal ini dapat digunakan untuk kepentingan belajar maupun berolahraga, dan dilihat dari sisi dampak negatifnya, teknologi dapat memanjakan dan membuat malas orang untuk beraktivitas, contoh yang nyata jika seseorang kecanduan game online dan media sosial, dapat melupakan aktivitas fisik dalam kesehariannya.

Kemanfaatan internet di Indonesia era milenial ini, di usia remaja pada anak sekolahan sudah dijadikan gaya hidup. Berdasarkan survei Asosiasi Penyelenggara Jasa Internet Indonesia (APJII) dan Teknopreneur tahun 2017 , sebanyak 54,13\% memanfaatkan internet untuk bermain game. Lebih dari 106 juta orang di Indonesia menggunakan media sosial 
setiap bulannya. Di mana $85 \%$ di antaranya mengakses media sosial melalui perangkat seluler atau smartphone". Perilaku seperti ini juga terjadi pada peserta didik di SMK N 3 Kintamani, ditunjukkan dengan beberapa kasus, cenderung peserta didik menggunakan smartphone saat kegiatan belajar mengajar maupun saat istirahat dari pada mereka berkunjung keperpustakaan untuk membaca buku.

Pergeseran perilaku akibat teknologi telah memunculkan perilaku prokrastinasi akademik bagi peserta didik, yaitu perilaku sering menunda mengikuti pelajaran, menunda untuk mengerjakan tugas yang diberikan oleh guru, dan tidak siapnya presentasi karena belum diselesaikannya pekerjaan atau tugas yang diberikan, sehingga tidak efisiensinya penggunaan waktu atau jam pembelajaran di kelasnya.

Berdasarkan observasi penulis selama dalam Proses Belajar Mengajar Pendidikan Jasmani Olahraga Kesehatan (PJOK) di SMKN 3 Kintamani, terdapat variasi antusiasme peserta didik di kelas X pada tahun pelajaran 2020/2021 terhadap mata pelajaran PJOK, sebagian peserta didik memiliki antusiasme pada mata pelajaran PJOK yang ditunjukkan dari sikapnya, seperti datang tepat waktu, selalu siap mengumpulkan tugas dan tidak terlambat dalam mengikuti pelajaran PJOK, serta terlihat semangat mereka melakukan aktivitas fisik. Hal ini menunjukkan minat peserta didik terhadap olahraga masih ada. Sebaliknya sebagian peserta didik putra menunjukkan sikap dan perilaku sering terlambat, jarang mengerjakan tugas yang diberikan oleh guru, dan tidak antusiasnya mengikuti pelajaran PJOK baik teori maupun praktek dilapangan.

Setelah ditelusuri lebih lanjut melalui wawancara langsung terhadap beberapa peserta didik, sebagian yang tidak berminat mengikuti pelajaran di sekolah khususnya PJOK, disebabkan oleh kecanduan media sosial, dan game online sejalan dengan penelitian yang dikemukakan oleh (Wissel, 2000), hal ini ditunjukkan pula dengan perilaku peserta didik yang suka menunda - nunda tugas atau pekerjaan (prokrastinasi) dari guru mata pelajaran lainnya, dibuktikan dari seringnya beberapa peserta didik dipanggil guru Bimbingan Konseling (BK) terkait beberapa kasus proses belajar mereka. Begitupun seringnya peserta didik ditemukan memainkan smartphone saat pelajaran sedang berlangsung.

Sehingga dampak dari perilaku tersebut dapat mengganggu suasana belajar di kelas. Hal ini juga didukung oleh beberapa kajian teori yang penulis kutip dari peneliti yang bernama (Chairunissa dalam Hanafi, 2016) pada artikelnya menyebutkan bahwa "ketika seseorang atau anak remaja pelajar yang sudah kecanduan media sosial facebook dan yang lainnya maka, 1) tidak perduli dengan lingkungan sekitarnya, 2) berkurangnya sosialisasi terhadap lingkungannya, 3) terganggunya kesehatan anak tersebut, 4) tidak ada aktivitas fisik yang dilakukan apalagi untuk berolahraga, 5) sering anak tersebut segala aktivitas yang mesti dilakukan terlambat apakah harusnya mandi, makan, tidur, dan 6) berkurangnya waktu belajar."

Berpijak dari uraian tersebut di atas penulis tertarik untuk mengetahui dan meneliti lebih lanjut permasalahan yang muncul dengan mengangkat peneliltian yaitu, Korelasi Prokrastinasi, Game Online, dan Media Sosial dengan Minat Berolahraga Peserta Didik Putra Kelas X SMK Negeri 3 Kintamani Tahun Pelajaran 2020/2021.

\section{METODE}

Penelitian ini tergolong penelitian deskriptif dengan jenis studi korelasi. Penelitian korelasi digunakan untuk mengukur derajat asosiasi antar dua variabel atau lebih yang menjadi dasar penelitian. Pendekatan yang digunakan dalam penelitian ini adalah pendekatan kuantitatif (Sugiyono \& Kuantitatif, 2009). Populasi dalam penelitian ini adalah seluruh peserta didik putra kelas X SMK Negeri 3 Kintamani tahun pelajaran 2020/2021 yang terdiri dari delapan kelas, yakni; kelas XAP1, XAP2, XAP3, XAP4, XAP5, XAP6, XAK, dan XMM, yang berjumlah 146. Sampel dalam penelitian ini berjumlah 75 sampel. Dengan sebaran sebagai berikut; kelas XAP1:12, kelas XAP2:10, kelas XAP3:10, XAP4:12, XAP5:7, XAP6:9, XAK:3, dan XMM:12 Siswa, secara keseluruhan sampel berjumlah 75 peserta didik putra. 
Teknik atau metode pengumpulan data yang digunakan dalam penelitian ini yaitu: Metode angket atau kuesioner. Kuesioner merupakan teknik pengumpulan data yang dilakukan dengan cara memberi seperangkat pertanyaan atau pernyataan tertulis kepada responden untuk dijawabnya (Sugiyono \& Kuantitatif, 2009)

Instrumen yang digunakan untuk mengumpulkan data dalam penelitian ini berupa angket dan dokumentasi. Angket digunakan untuk memperoleh data tentang hubungan prokrastinasi, game online dan media sosial terhadap minat berolahraga peserta didik putra kelas X SMKN 3 Kintamani tahun pelajaran 2020/2021. Instrumen yang digunakan untuk mengumpulkan data sebelumnya diuji pakar (expert judgement) dalam hal ini setelah instrumen dikonstruksi tentang aspek -aspek tertentu maka selanjutnya dikonsultasikan dengan ahli kemudian diminta pendapatnya tentang instrumen yang telah tersusun dan diuji empirik terlebih dahulu. Hal ini bertujuan untuk mengetahui relevansi, validitas dan reliabelitasnya.

Pada penelitian ini terdapat empat variabel, yaitu tiga variabel independen yang terdiri dari prokrastinasi (X1), game online (X2) dan media sosial (X3), serta satu variabel dependen yaitu minat berolahraga $(Y)$.

Dalam penelitian ini uji linier menggunakan SPSS26 for windows. Setelah dilakukan perhitungan kemudian apabila Fhitung lebih kecil atau sama dengan Ftabel berarti hubungan antar variabel independen dengan dependen berpola linear. Sebaliknya, jika Fhitung lebih besar dari Ftabel berarti non-linear. Analisis bivariat digunakan untuk menguji hipotesis pertama, kedua dan ketiga yaitu untuk menguji koefisien antara variabel independen dengan variabel dependen, rumus yang digunakan adalah korelasi Pearson Product Moment.

\section{HASIL DAN PEMBAHASAN HASIL}

Data hasil penelitian terdiri dari tiga variabel independen,yaitu prokrastinasi $(x 1)$, game online $(\mathrm{x} 2)$ dan media sosial $(\mathrm{x} 3)$, dan satu variabel dependen yaitu minat berolahraga (Y). Untuk mendeskripsikan dan melihat hubungan antar variabel independen dan variabel dependen dalam penelitian ini. variabel prokrastinasi (x1) memiliki rata-rata secara statistik dari prokrastinasi sebesar 63,27 dan mediannya adalah 64 yang memiliki standar deviasi 9,819.dengan modus 6 , sedangkan skor maksimumnya adalah 86 dan skor minimumnya adalah 36.

Hasil distribusi kecenderungan data variabel game online dapat juga digambarkan dengan diagram lingkaran sebagai berikut.

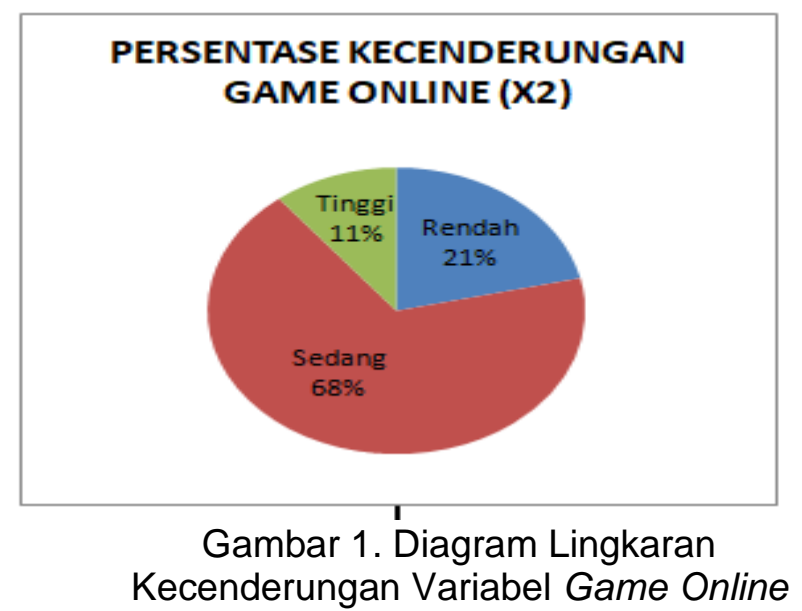

Hasil di atas menunjukkan bahwa cenderung peserta didik dalam bermain game online kategori sedang yaitu $68 \%, 21 \%$ peserta didik dalam bermain game online kategori rendah. Dan $11 \%$ peserta didik dalam bermain game online kategori tinggi. Berdasarkan tabel distribusi frekuensi kecenderungan di atas, dapat disimpulkan bahwa bermain game online peserta didik putra kelas X SMK Negeri 3 Kintamani tahun pelajaran 2020/2021 tergolong 
sedang dan mengarah ke rendah atau masih bisa dikatakan wajar. Variabel ini diukur menggunakan angket dengan 25 butir pernyataan yang disebar pada peserta didik putra kelas X SMK Negeri 3 Kintamani tahun pelajaran 2020/2021. Dari data hasil penelitian yang telah diperoleh pada tabel 4.3 pada bagian media sosial $(x 3)$ di atas, skor maksimum adalah sebesar 76 sedangkan skor minimumnya adalah 61. Rata - rata secara statistik dari Media Sosial sebesar 67,64 dan mediannya adalah 67,00 dengan modus 67 yang memiliki standar deviasi 3,92. Hasil di atas menunjukkan bahwa cenderung peserta didik dalam menggunakan media sosial kususnya facebook pada kategori sedang yaitu $63 \%$. Hanya $24 \%$ kategori rendah. Sedangkan ada $13 \%$ peserta didik dalam menggunakan media sosial facebook kategori tinggi.

Penggunaan media sosial facebook peserta didik putra kelas X SMK Negeri 3 Kintamani tahun pelajaran 2020/2021 tergolong sedang atau dalam kondisi yang wajar. Hasil di atas menunjukkan bahwa cenderung peserta didik memiliki minat berolahraga pada kategori sedang yaitu $69 \%$. Hanya $20 \%$ saja peserta didik memiliki minat berolahraga kategori rendah. Sedangkan ada $11 \%$ peserta didik memiliki minat berolahraga kategori tinggi. Minat berolahraga peserta didik putra kelas X SMK Negeri 3 Kintamani tahun pelajaran 2020/2021 tergolong sedang.

\section{PEMBAHASAN}

Berdasarkan Hasil analisis data menunjukkan adanya korelasi positif antara prokrastinasi dengan minat berolahraga peserta didik putra kelas X SMK Negeri 3 Kintamani Tahun Pelajaran 2020/2021. Melalui analisis korelasi Pearson Product Moment diperoleh nilai $r$ hitung sebesar 0,496 sedangkan nilai untuk $r$ tabel adalah 0,227 dengan $\mathrm{N}=75$ pada taraf signifikansi $5 \%$. Jadi nilai $r$ hitung lebih besar dari $r$ tabel sehingga dapat disimpulkan bahwa ada korelasi yang signifikan antara variabel prokrastinasi dengan minat berolahraga. Karena $r$ hitung atau pearson correlations dalam analisis ini bernilai positif, artinya hubungan antara kedua variabel tersebut bersifat positif atau dengan kata lain semakin tinggi tingkat prokrastinasinya maka akan semakin meningkat minat berolahraga peserta didik putra kelas X SMK Negeri 3 Kintamani tahun pelajaran 2020/2021.

Hasil penelitian ini, membuktikan bahwa tingkat prokrastinasi pada peserta didik putra kelas X SMK Negeri 3 Kintamani Tahun Pelajaran 2020/2021, cenderung hanya melakukan penundaan dalam aktivitas belajar beserta tugas-tugasnya (prokrastinasi akademik). Hal ini sesuai dengan yang disampaikan oleh ((Arifin et al., 2017)) bahwa prokrastinasi adalah suatu kebiasaan menunda-nunda kegiatan atau tidak membuat tugas secara tepat waktu, yang identik dengan prokrastinasi akademik. Begitupun dalam kajian teori yang disampaikan oleh (Jamalong, 2016) bahwa, penyebab dari munculnya prokrastinasi karena terjadinya perkembangan teknologi modern, sehingga prioritas dalam kehidupan remaja tidak ada lagi atau bisa dikatakan menurun sehingga ada kecenderungan bertindak asosial, terjadi kemalasan dan akhirnya pelampiasannya bermain game / game online.

Situasi seperti ini memunculkan berbagai permasalahan secara psikologis seperti adanya peningkatan emosional, kecemasan, rasa takut, rendah diri dan prustasi, oleh karena itu untuk mengurangi permasalahan psikologis tersebut peserta didik mengalihkan aktivitasnya pada kegiatan berolahraga dimana bisa membangun kembali rasa kepercayaan diri, menghilangkan kecemasan, stress dan lainnya, ini sesuai dengan tujuan daripada berolahraga seperti yang disampaikan dalam kajian teori tentang hakikat olahraga oleh (Prasetyo, 2013) sebagai berikut:

"Self Esteem,being able to participate in activities with a sense of independence to enhances self cofidence and how you feel about your self and strees level, exercise equip you to cope with streess and better wich in turn leads to better work performance. You will also find in easier to relax. "Artinya bahwa harga diri, mampu berpartisipasi dalam setiap aktivitas olahraga dengan rasa kemandirian untuk meningkatkan kepercayaan diri. Dengan latihan atau berolahraga penghargaan pada diri sendiri akan merasa lebih baik yang pada akhirnya 
mengarah pada kinerja yang lebih baik dari sebelumnya. Sebagaimana yang dipaparkan dalam buku (Irwanto, 2016) bahwa manfaat kegiatan olahraga secara psikologis dapat menghilangkan rasa stress, mengurangi depresi, kecemasan, sebagai anti aging, dan meningkatkan perasaan bahagia.

Sehingga dapat disimpulkan bahwa dari hasil penelitian yang dilakukan pada peserta didik putra kelas X SMK Negeri 3 Kintamani tahun pelajaran 2020/2021, terjadi korelasi positif antara prokrastinasi dengan minat berolahraga.Tetapi Hasil penelitian tersebut berbeda dengan hasil penelitian Desy Yunita Utami, 2019 dalam konteks "Hubungan Minat Olahraga dan Psychological Well-Being terhadap Prokrastinasi peserta didik di SMA Negeri 1 Muntilan”, di mana pada hasil penelitiannya dijelaskan bahwa terdapat hubungan negatif atau berlawanan arah pada minat olahraga dengan prokrastinasi. Artinya jika minat olahraga tinggi maka tingkat prokrastinasi rendah.

Berdasarkan hasil analisis data untuk hipotesis yang kedua menunjukkan bahwa terdapat korelasi negatif dan signifikan antara game online dengan minat berolahraga. Hal ini didapatkan dari analisis korelasi product moment yang menyatakan bahwa nilai $r$ hitung lebih besar dari $r$ tabel yaitu $-0,241>0,227$. Dapat disimpulkan bahwa apabila game online tinggi maka minat berolahraga rendah.

Game online adalah bentuk permainan yang dapat dimainkan oleh banyak orang melalui jaringan atau koneksi internet melalui berbagai media. Intensitas bermain game online lebih banyak dilakukan anak usia remaja atau anak sekolahan, yang telah menimbulkan berbagai dampak positif maupun negatif. Sebagaimana yang disampaikan oleh (Arifin et al., 2017) dampak negatif permainan game oline diantaranya menumbuhkan perilaku malas untuk belajar, malas untuk beraktivitas, malas untuk bergaul dalam pergaulan sosial sehingga tidak peka terhadap lingkungan sekitar. Sehingga game online erat kaitannya dengan minat berolahraga, dimana semakin tinggi peserta didik larut dalam permainan game online maka semakin rendah keinginan untuk beraktivitas sehingga minat berolahraga pun menjadi rendah.

Hasil penelitian ini sesuai dengan penelitian yang dilakukan oleh Drajat Edy kurniawan pada tahun 2017 dengan judul "Pengaruh Intensitas Bermain Game Online terhadap Perilaku Prokrastinasi Akademik pada Mahasiswa Bimbingan Konseling Universitas PGRI Yogyakarta" dijelaskan bahwa tedapat pengaruh yang signifikan antara bermain game online dengan perilaku prokrastinasi. Sehingga jika intensitas bermain game tinggi maka akan berpengaruh terhadap perilaku prokrastinasi(Husdarta, 2009). Sedangkan prokrastinasi dengan minat berolahraga memiliki hubungan yang positif sehingga dapat disimpulkan bahwa aktivitas game online memiliki hubungan yang signifikan dengan minat berolahraga peserta didik didik putra kelas X SMK Negeri 3 Kintamani tahun pelajaran 2020/2021.

Berdasarkan Hasil analisis data untuk hipotesis ketiga menunjukkan tidak ada korelasi secara signifikan antara media sosial dengan minat berolahraga peserta didik putra kelas $\mathrm{X}$ SMK Negeri 3 Kintamani tahun pelajaran 2020/2021. Melalui analisis korelasi Pearson Product Moment diperoleh nilai $r$ hitung sebesar $-0,197$ sedangkan nilai untuk $r$ tabel adalah 0,227 dengan $\mathrm{N}=75$ pada taraf signifikansi $5 \%$. Jadi nilai $r$ hitung lebih kecil dari $r$ tabel sehingga dapat disimpulkan bahwa tidak ada korelasi yang signifikan antara variabel media sosial dengan minat berolahraga peserta didik putra kelas X SMK Negeri 3 Kintamani tahun pelajaran 2020/2021. Hasil Penelitian ini sesuai dengan penelitian yang dilakukan oleh Salahudin Firman dan Anung Priambodo pada tahun 2017 dengan judul" Hubungan Pemakaian Smartphone terhadap Aktivitas Olahraga Sehari-hari Siswa Kelas VIII SMP Negeri 1 Trawas" diperoleh nilai product moment sebesar 0,004.dengan kesimpulan bahwa tidak ada hubungan yang signifikan antara pemakaian smartphone terhadap aktivitas olahraga seharihari siswa kelas VIII SMP Negeri 1 Trawas.

Berdasarkan Hasil analisis data untuk hipotesis keempat melalui uji regresi linier berganda dan uji $\mathrm{F}$ menunjukkan bahwa prokrastinasi $(\mathrm{x} 1)$, game online(x2), dan media sosial $(x 3)$ secara bersama-sama berpengaruh secara siginifikan terhadap minat berolahraga (Y), dibuktikan dari hasil output "ANOVA" bahwa nilai signifikansi (Sig.) dalam uji $\mathrm{F}$ adalah 
Sig.0,000<0,05. Dan diketahui bahwa taraf signifikansi untuk uji $F$ diperoleh nilai Fhitung sebesar 12.249 dengan nilai $f$ tabel sebesar 2,73, sehingga nilai Fhitung > Ftabel atau 12,249>2,73. Berdasarkan output nilai determinasi atau $R$ adalah sebesar 0,584 atau sama dengan $58,4 \%$. Artinya bahwa variabel prokrastinasi (x1), game online (x2) dan media sosial (x3) secara simultan atau bersama - sama berkorelasi atau berpengaruh dengan variabel minat berolahraga $(Y)$ sebesar $58,4 \%$, sedangkan sisanya dipengaruhi oleh variabel lain atau variabel yang tidak diteliti sebesar $48,4 \%$. Sehingga dapat disimpulkan bahwa prokrastinasi, game online, dan media sosial terdapat korelasi atau berpengaruh dengan minat berolahraga peserta didik putra kelas X SMKN 3 Kintamani tahun pelajaran 2020/2021.

\section{SIMPULAN DAN SARAN}

Kesimpulan yang dapat diambil berdasarkan hasil analisis data tentang "Korelasi Prokrastinasi, Game Online dan Media Sosial denganMinat Berolahraga Peserta Didik Putra Kelas X SMK Negeri 3 Kintamani Tahun Pelajaran 2020/2021" yaitu sebagai berikut:

1. Terdapat hubungan positif dan signifikan antara prokrastinasi dengan minat berolahraga peserta didik putra kelas X SMK Negeri 3 Kintamani Tahun Pelajaran 2020/2021.

2. Terdapat hubungan negatif dan signifikan antara game online dengan minat berolahraga peserta didik putra kelas X SMK Negeri 3 Kintamani Tahun Pelajaran 2020/2021.

3. Tidak terdapat hubungan secara signifikan antara prokrastinasi dengan minat berolahraga peserta didik putra kelas X SMK Negeri 3 Kintamani Tahun Pelajaran 2020/2021.

4. Terdapat korelasi yang signifikan antara prokrastinasi, game online dan media sosial secara bersama - sama dengan minat berolahraga.

\section{DAFTAR PUSTAKA}

Arifin, Z., Fallo, I. S., \& Sastaman, P. (2017). Identifikasi bakat olahraga siswa sekolah dasar di Pontianak Barat. Jurnal Pendidikan Olah Raga, 6(2), 129-139.

Candra, A. T. (2020). Analisis Minat Dan Bakat Olahraga Berbasis Kearifan Lokal di Kabupaten Banyuwangi. Jurnal Pendidikan Kesehatan Rekreasi, 6(2), 177-189.

Diananda, A. (2019). Psikologi remaja dan permasalahannya. ISTIGHNA: Jurnal Pendidikan Dan Pemikiran Islam, 1(1), 116-133.

Husdarta, H. J. S. (2009). Manajemen pendidikan jasmani. Bandung: Alfabeta.

INDONESIA, P. R. (2007). Undang-undang Republik Indonesia Nomor 3 Tahun 2005 Tentang Sistem Keolahragaan Nasional.

Irwanto. (2016). Psikologi Umum. Gramedia Pustaka Utama.

Jamalong, A. (2016). Peningkatan prestasi olahraga nasional secara dini melalui pusat pembinaan dan latihan pelajar (PPLP) dan pusat pembinaan dan latihan mahasiswa (PPLM). Jurnal Pendidikan Olah Raga, 3(2), 156-168.

Prasetyo, Y. (2013). Kesadaran masyarakat berolahraga untuk peningkatan kesehatan dan pembangunan nasional. Medikora, 11(2).

Sugiyono, M. P. P., \& Kuantitatif, P. (2009). Kualitatif, dan R\&D, Bandung: Alfabeta. Cet. Vii.

Wissel, H. (2000). Bola basket: dilengkapi dengan program pemahiran teknik dan taktik. Raja Grafindo. 